Sains Malaysiana 48(3)(2019): 621-627

http://dx.doi.org/10.17576/jsm-2019-4803-15

\title{
Incidence and Risk Factors of Post-Tonsillectomy Haemorrhage in Patients Operated during the 2012-2016 Period at ENT Department Hospital Serdang, Malaysia
}

(Kejadian dan Faktor Risiko Pendarahan Selepas Tonsilektomi bagi Pesakit yang Dibedah Sepanjang Tempoh 2012-2016 di Jabatan ENT Hospital Serdang, Malaysia)

\author{
SETHU T. SUBHA*, ATIQAH FARAH, Z., CHONG, K.M. \\ NOR ASHIKIN, A.H. \& MUHAMMAD FIKRI, S.
}

\begin{abstract}
Tonsillectomy is the most common operation performed in the field of Ear, Nose and Throat (ENT) Surgical speciality. Post-tonsillectomy haemorrhage remains a significant complication leading to morbidity and occasional mortality. The main objective of this study was to evaluate the incidence and risk factors of post-tonsillectomy haemorrhage in a cohort of patients who had been operated at our institution. This retrospective cohort study reviewed the medical records of all patients who underwent tonsillectomy from 1st January 2012 to 31 st December 2016. Data on patient's age, gender, race, smoking habit, indication for tonsillectomy, duration and technique of surgery, usage of postoperative drugs and management were recorded. Out of 315 patients included this study, 54.9\% were adults (12 years and above) and majority (86.3\%) of them were of Malay descent. The common indication for tonsillectomy was recurrent tonsillitis $(84.4 \%)$. This study showed significant associations $(\mathrm{p}<0.05)$ between age, smoking and the use of steroids with post-tonsillectomy haemorrhage. However, there was no significant association between gender, race, use of post-operative drugs (non-steroidal anti-inflammatory drugs, antibiotics), duration of surgery, the technique of surgery and post-tonsillectomy haemorrhage. The incidence of post-tonsillectomy haemorrhage in our population was $10.5 \%(\mathrm{n}=33)$ and among them, $54.5 \%(\mathrm{n}=18)$ required surgical intervention. Our study demonstrated that older patients (12 years and above), smokers and the use of steroids during the post-operative period have increased the risk of post-tonsillectomy haemorrhage. An awareness of these risk factors should help to minimize the post-tonsillectomy haemorrhage and improve the patient outcomes.
\end{abstract}

Keywords: Post tonsillectomy haemorrhage (PTH); risk factors; smokers; steroids

ABSTRAK

Tonsilektomi adalah pembedahan yang paling biasa dilakukan dalam bidang kepakaran Telinga, Hidung dan Tekak (ENT). Pendarahan selepas pembedahan tonsilektomi adalah komplikasi yang ketara membawa kepada morbiditi dan mortaliti sekali sekala. Objektif utama kajian ini adalah untuk menilai kejadian dan faktor risiko untuk mendapat pendarahan selepas pembedahan tonsilektomi dalam kohort pesakit yang telah menjalani pembedahan di institusi kami. Kajian kohort retrospektif ini mengkaji rekod perubatan daripada semua pesakit yang menjalani tonsilektomi dari 1 Januari 2012 hingga 31 Disember 2016. Data pesakit seperti umur, jantina, bangsa, tabiat merokok, petunjuk untuk menjalani tonsilektomi, tempoh dan teknik pembedahan, penggunaan ubat-ubatan dan pengurusan selepas pembedahan telah direkodkan. Antara 315 pesakit termasuk kajian ini, 54.9\% adalah orang dewasa (12 tahun ke atas) dan majoriti (86.3\%) daripadanya adalah berbangsa Melayu. Penunjuk umum untuk pembedahan adalah tonsillitis berulang $(84.4 \%)$ dalam kalangan pesakit kami. Kajian ini menunjukkan kaitan yang signifikan ( $<<0.05)$ antara umur, merokok dan penggunaan steroid dengan pendarahan selepas pembedahan tonsilektomi. Walau bagaimanapun, tidak terdapat hubungan yang signifikan antara jantina, bangsa, penggunaan ubat-ubatan selepas pembedahan (NSAIDS, antibiotik), tempoh pembedahan, teknik pembedahan dengan pendarahan selepas pembedahan tonsilektomi. Insiden pendarahan selepas tonsilektomi dalam populasi kami adalah $10.5 \%(\mathrm{n}=33)$ dan antara mereka $54.5 \%(\mathrm{n}=18)$ memerlukan rawatan intervensi surgeri. Kajian ini menunjukkan bahawa pesakit yang lebih tua (12 tahun ke atas), perokok dan penggunaan steroid dalam tempoh selepas pembedahan mempunyai risiko yang lebih tinggi untuk mendapat pendarahan selepas pembedahan. Kesedaran mengenai faktor risiko ini harus membantu meminimumkan pendarahan selepas pembedahan tonsilektomi dan meningkatkan penjagaan dan keadaan pesakit.

Kata kunci: Faktor risiko; pendarahan pasca-tonsilektomi (PTH); perokok; steroid 


\section{INTRODUCTION}

Tonsillectomy is one of the most common worldwide surgical procedures performed by Otolaryngologists (ENT surgeons) which is usually uncomplicated (Al-Ani 2012; Tami et al. 1987). Recurrent tonsillitis, obstructive sleep apnoea and peritonsillar abscess are the most common indications (Szeremeta et al. 1996). Various new techniques have been developed to replace the conventional cold dissection method for tonsillectomy in order to reduce the post-operative pain and haemorrhage (Al-Shehri 2014; Tami et al. 1987). The rate of post-tonsillectomy haemorrhage is between $0.28 \%$ and $20 \%$ (Liu et al. 2001). Posttonsillectomy haemorrhage is an uncommon but potentially devastating event that can lead to airway obstruction, hypovolemic shock, and death if the bleeding is severe (Cohen et al 2008; Collison et al. 2000). Many factors which might affect the risk of post-tonsillectomy haemorrhage are demographic characteristics, hemodynamic status, surgical indications, anaesthetic and surgical techniques (Tami et al. 1987). This study was conducted to evaluate the incidence of post-tonsillectomy haemorrhage, associated risk factors and its management.

\section{MATERIALS AND METHODS}

The study was carried out after obtaining the institutional ethical board approval. We performed a retrospective review of patients who were subjected for tonsillectomy at the ENT Department over a five-year period from January 2012 to December 2016. The exclusion criteria were the patients with coagulation disorder, anticoagulant drugs, cardiac and liver failure. Data on patients' demographics, smoking habit and use of post-operative drugs i.e. nonsteroidal anti-inflammatory drugs (NSAIDS), steroids and antibiotics were collected. The technique, duration of tonsillectomy surgery and management of posttonsillectomy haemorrhage were also recorded. The data were analyzed using IBM SPSS statistic version 22.0. For descriptive analysis, mean, standard deviation, frequency and percentage were used. An analytic statistical test was used to determine the association between variables. Kolmogorov-Smirnov test was used to test the normality for quantitative variables such as gender, the technique of surgery, smoking and usage of post-operative NSAIDs, steroids and antibiotics. Chi-Square test was used to analyze the association of gender, the technique of surgery, smoking and use of post-operative NSAIDs. Management was analyzed by descriptive statistics and percentage. ChiSquare test and Fisher's exact test was used to analyze the association between variables. In all statistical analyses, a 'p' value of less than 0.05 (95\% confidence interval) was considered to be statistically significant.

\section{RESULTS}

A total of 315 patients had undergone tonsillectomy during the five-year period. Among these, 173 were above 12 years of age and 142 were below 12 years old (Figure 1).

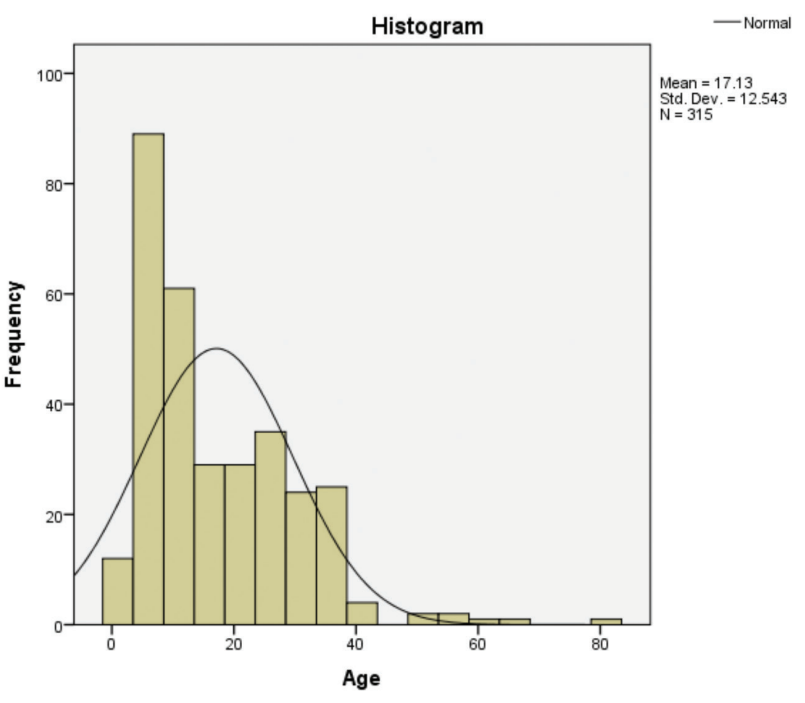

FIGURE 1. Distribution of age among tonsillectomy patients

The age group was not normally distributed and skewed to the right with the median of 13 . Out of the 315 patients, the minimum age was one-year old and the maximum age was 80 years old. The interquartile range was 19,1 st quartile was 7 and 3rd quartile was 26. The variance was 157.33 and the standard deviation was 12.54 . Of these, 142 of the patients were in the group of 'below 12 years old' which contributed to $45.1 \%$ of the patients and 173 of the patients were in the group of ' 12 years old and above' which contributed to $54.9 \%$ of the patients.

The study cohort consisted of 155 males and 160 females. The result showed that the percentage of female patients $(50.8 \%, n=160)$ was slightly higher than that of male patients $(49.2 \%, n=155)$. Out of 315 patients, majority of patients were Malay $(n=272,86.3 \%)$, followed by Indian $(n=20,6.3 \%)$, others $(n=13,4.1 \%)$ and Chinese $(n=10,3.2 \%)$ (Table 1).

Among the 315 patients, $266(84.4 \%)$ of the patients underwent tonsillectomy have recurrent tonsillitis and 85 (27.0\%) of the patients have obstructive sleep apnoea. There were $17.1 \%(\mathrm{~N}=54)$ of the patients underwent tonsillectomy due to other indications such as adenotonsillar hypertrophy, quinsy (peritonsillar abscess) and suspicion of malignancy.

The analysis of data showed that the percentage of patients with post-tonsillectomy haemorrhage is $10.5 \%$ $(n=33)$ (Table 2).

Among the thirty-three patients who had posttonsillectomy haemorrhage, $78.8 \%(n=26)$ of the patients was 12 years old and above. Our data showed that $57.6 \%$ of the post-tonsillectomy haemorrhage patients were males and $42.4 \%$ were females. Most of the post-tonsillectomy haemorrhage patients were Malay $81.8 \%(\mathrm{~N}=27)$, followed by other races $(\mathrm{N}=3,9.1 \%)$, Indian $(\mathrm{N}=2,6.1 \%)$ and Chinese $(\mathrm{N}=1,3.0 \%)$ (Table 3). 
TABLE 1. Distribution of socio-demographic factors among tonsillectomy patients

\begin{tabular}{lcc}
\hline Sociodemographic factors & Frequency $(\mathrm{n})$ & Percentage $(\%)$ \\
\hline Age Group $(N=315)$ & & \\
Below 12 years old $(<12)$ & 142 & 45.1 \\
12 years old and above $(\geq 12)$ & 173 & 54.9 \\
Gender $(N=315)$ & & \\
Male & 155 & 49.2 \\
Female & 160 & 50.8 \\
Races $(N=315)$ & & \\
Malay & 272 & 86.3 \\
Chinese & 10 & 3.2 \\
Indian & 20 & 6.3 \\
Others & 13 & 4.1 \\
\hline
\end{tabular}

TABLE 2. Distribution of post-tonsillectomy haemorrhage in tonsillectomy patients

\begin{tabular}{ccc}
\hline Post-tonsillectomy haemorrhage & Frequency $(\mathrm{n})$ & Percentage $(\%)$ \\
\hline No & 282 & 89.5 \\
Yes & 33 & 10.5 \\
Total & 315 & 100 \\
\hline
\end{tabular}

TABLE 3. Distribution of socio-demographic factors among post-tonsillectomy haemorrhage patients

\begin{tabular}{lcc}
\hline Sociodemographic factors & Frequency $(\mathrm{n})$ & Percentage $(\%)$ \\
\hline Age Group $(N=33)$ & 7 & \\
Below 12 years old $(<12)$ & 26 & 21.2 \\
12 years old and above $(\geq 12)$ & & 78.8 \\
Gender $(N=33)$ & 19 & 57.6 \\
Male & 14 & 42.4 \\
Female & & \\
Races $(N=33)$ & 27 & 81.8 \\
Malay & 1 & 3.0 \\
Chinese & 2 & 6.1 \\
Indian & 3 & 9.1 \\
Others & & \\
\hline
\end{tabular}

Regarding the surgical techniques, $87.9 \%$ (29) post-tonsillectomy haemorrhage patients underwent cold dissection method and $12.1 \%$ (4) patients had hot dissection method. In this study cohort, 26 (78.8\%) of post-tonsillectomy haemorrhage patients were nonsmokers, while seven $(21.2 \%)$ of post-tonsillectomy haemorrhage patients had positive history of smoking. All of the post-tonsillectomy haemorrhage patients were given post-operative NSAIDs, but only $18.2 \%$ (6) patients had received steroids after tonsillectomy. Further analysis of post-tonsillectomy haemorrhage patients showed that $93.9 \%$ (31) of them used antibiotics after tonsillectomy. Duration of the surgery was less than 30 min in $6.1 \%$ (2) patients (Table 4).

Among the 33 patients who experienced posttonsillectomy haemorrhage, $54.5 \%(\mathrm{~N}=18)$ required surgical management. The remaining $45.5 \% \quad(\mathrm{~N}=15)$ of the patients were managed conservatively. There is a significant association between age group and posttonsillectomy haemorrhage $(p=0.004)$. Patients who underwent tonsillectomy above the age of 12 years old have the higher chance of post-tonsillectomy haemorrhage (Table 5).

There was a significant association between smoking and post-tonsillectomy haemorrhage, where the $p$-value is 0.007 . Smokers have a higher risk to develop posttonsillectomy haemorrhage. Data analysis showed that there are no significant association between the various indications of tonsillectomy and post-tonsillectomy haemorrhage ( $p=0.799)$. There was a significant association between the use of steroids $(p=0.028)$ with posttonsillectomy haemorrhage. Patients who were given steroids have a higher risk to develop post-tonsillectomy haemorrhage (Table 6). 
TABLE 4. Distribution of risk factors among post-tonsillectomy haemorrhage patients

\begin{tabular}{lcc}
\hline Risk factors & Frequency $(\mathrm{n})$ & Percentage $(\%)$ \\
\hline Technique of surgery $(N=33)$ & 29 & 87.9 \\
$\quad$ Cold dissection method & 4 & 12.1 \\
$\quad$ Hot dissection method & & \\
Smoking $(N=33)$ & 26 & 78.8 \\
$\quad$ Smokers & 7 & 21.2 \\
$\quad$ Non smokers & & \\
Use of post-operative NSAIDs $(N=33)$ & 33 & 00 \\
$\quad$ Yes & 0 & \\
$\quad$ No & & 81.8 \\
Use of steroids $(N=33)$ & 27 & 18.2 \\
$\quad$ No & 6 & 6.1 \\
$\quad$ Yes & & 93.9 \\
Use of antibiotics $(N=33)$ & 2 & 6.1 \\
$\quad$ No & 31 & 93.9 \\
$\quad$ Yes & & \\
Duration of procedure $(N=33)$ & 2 & \\
$\quad$ Less than 30 min & 31 & \\
$\quad$ More than 30 min &
\end{tabular}

TABLE 5. Association between socio-demographic factors and post-tonsillectomy haemorrhage

\begin{tabular}{|c|c|c|c|c|c|}
\hline \multirow[t]{2}{*}{ Socio-demographic factors } & \multicolumn{2}{|c|}{$\begin{array}{c}\text { Post-tonsillectomy haemorrhage } \\
\text { frequency }(\%)\end{array}$} & \multirow[t]{2}{*}{$x^{2}$ value } & \multirow[t]{2}{*}{$\mathrm{df}$} & \multirow[t]{2}{*}{$p$ value } \\
\hline & No & Yes & & & \\
\hline \multicolumn{6}{|l|}{ Age Group $(N=315)$} \\
\hline Below 12y/o $(\mathrm{N}=303)$ & $135(95.1)$ & $7(4.9)$ & 8.481 & 1 & 0.004 \\
\hline $12 \mathrm{y} / \mathrm{o}$ and above $(\mathrm{N}=12)$ & $147(85.0)$ & $26(15.0)$ & & & \\
\hline \multicolumn{6}{|l|}{ Gender $(N=315)$} \\
\hline Male $(\mathrm{N}=155)$ & $136(87.7)$ & $19(12.3)$ & 1.033 & 1 & 0.309 \\
\hline Female $(\mathrm{N}=160)$ & $146(91.3)$ & $14(8.8)$ & & & \\
\hline \multicolumn{6}{|l|}{ Race $(N=315)$} \\
\hline Malay $(\mathrm{N}=272)$ & $245(90.1)$ & $27(9.9)$ & - & - & $0.423 *$ \\
\hline Non-Malay (N=43) & $37(86.0)$ & $6(14.0)$ & & & \\
\hline
\end{tabular}

\section{DISCUSSION}

Tonsillectomy with or without adenoidectomy is one of the oldest and most common surgical procedures performed by Otolaryngologists world-wide (Al-Ani 2012; Arora et al. 2015; Bhattacharyya 2001; Liu et al. 2001; Spektor et al. 2016). Tonsillectomy has been recommended for patients with chronic recurrent tonsillitis, tonsillar hypertrophy causing obstructive sleep apnoea, peritonsillar abscess and suspicion of malignancy (Negm et al. 2017). Tonsillectomy has been shown to be effective in reducing the clinical burden and improve the quality of life in patients with recurrent tonsillitis (Bhattacharyya 2001; Wetmore 2017). Post-tonsillectomy haemorrhage remains a persistent and significant complication with associated morbidity and occasional mortality (Arora et al. 2015; Tami et al. 1987). Post-tonsillectomy bleeding is a distressing event for the patients as well as for the surgeons.
Although there are innumerable studies conducted on PTH, there is still significant variation in the rates of PTH. The incidence of PTH occurs at a rate of $0.28 \%$ and $20 \%$ (Al-Shehri 2014; Liu et al. 2001). This wide range of bleeding rates may be due to the diversity in the definition of PTH among Otorhinolaryngology community. Blakely et al. (2009) in his review on 63 studies suggested that the maximum acceptable PTH rate is $13.9 \%$. Our posttonsillectomy haemorrhage rate $10.5 \%$, is relatively higher compared to that reported by other studies (Al-Ani 2012; Collison et al. 2000; Kwok et al. 2018). Harju and Numminen (2017) in their study found more or less similar rate $(12 \%)$ to our results.

Our retrospective study of post-tonsillectomy haemorrhage with or without adenoidectomy consisted of a broad range of ages. We classified patients younger than 12 years as children and patients 12 years and older 
TABLE 6. Association between risk factors and post-tonsillectomy haemorrhage

\begin{tabular}{|c|c|c|c|}
\hline \multirow[t]{2}{*}{ Risk Factors } & \multicolumn{2}{|c|}{$\begin{array}{l}\text { Post- tonsillectomy haemorrhage } \\
\text { Freq }(\%)\end{array}$} & \multirow[t]{2}{*}{$p$-value } \\
\hline & No & Yes & \\
\hline \multicolumn{4}{|l|}{ Technique of Surgery $(N=315)$} \\
\hline Cold dissection method $(\mathrm{N}=268)$ & $239(89.1)$ & $29(10.9)$ & $0.799 *$ \\
\hline Hot dissection method $(\mathrm{N}=47)$ & $43(91.5)$ & $4(8.5)$ & \\
\hline \multicolumn{4}{|l|}{ Smoking $(N=315)$} \\
\hline Nonsmokers $(\mathrm{N}=291)$ & $265(91.1)$ & $26(8.9)$ & $0.007 *$ \\
\hline Smokers $(\mathrm{N}=24)$ & $17(70.8)$ & $7(29.2)$ & \\
\hline \multicolumn{4}{|l|}{ Use of post-operative NSAIDs $(N=315)$} \\
\hline No $(\mathrm{N}=3)$ & $3(100)$ & $0(0.0)$ & $1.000 *$ \\
\hline Yes $(\mathrm{N}=312)$ & $279(89.4)$ & $33(10.6)$ & \\
\hline \multicolumn{4}{|l|}{ Use of steroids $(N=315)$} \\
\hline No $(N=291)$ & $264(90.7)$ & $27(9.3)$ & $0.028 *$ \\
\hline Yes $(\mathrm{N}=24)$ & $18(75.0)$ & $6(25.0)$ & \\
\hline \multicolumn{4}{|l|}{ Use of antibiotics $(N=315)$} \\
\hline No $(\mathrm{N}=11)$ & $9(81.8)$ & $2(18.2)$ & $0.323^{*}$ \\
\hline Yes $(N=304)$ & $273(89.8)$ & $31(10.2)$ & \\
\hline \multicolumn{4}{|l|}{ Duration of procedure $(N=315)$} \\
\hline Less than $30 \min (\mathrm{N}=41)$ & $39(95.0)$ & $2(5.0)$ & $0.281 *$ \\
\hline More than $30 \min (\mathrm{N}=274)$ & $243(88.7)$ & $31(11.3)$ & \\
\hline
\end{tabular}

as adults. Among the total 315 post-tonsillectomy patients, $54.9 \%$ of were adults. Various studies (Maksimovic et al. 2007; Negm et al. 2007; Tomkinson et al. 2012; Windfuhr et al. 2005) had reported that older age has a higher risk of PTH. Our study also demonstrated a similar finding, patients who were aged 12 years and above $(78.8 \%)$ had an increased likelihood of PTH. This is probably related to the fact that adult patients have repeated infections which leads to more fibrosis and more vigorous surgery (Aljabr et al. 2016). Our study also showed that patients underwent tonsillectomy for recurrent tonsillitis have a higher likelihood of PTH compared to other indications like obstructive sleep apnoea. This is in accordance with studies by Kwok et al. (2018) and Perkins et al. (2012).

There is inconsistency regarding the gender as a risk factor for PTH. Studies by Coordes et al. (2016) and Windfuhr et al. (2005) found significantly higher rate of PTH in males. Where else our analysis and other studies (Alexander et al. 2004; Kwok et al. 2018; Negm et al. 2017; Perkins et al. 2012) did not show any statistically significant difference in PTH rates between genders (Kwok et al. 2018; Negm et al. 2017; Perkins et al. 2012).

In our cohort study, the majority of our posttonsillectomy haemorrhage patients were Malays. Bhattacharyya et al. (2014) in his study found that black and Hispanic children were more likely to suffer from a post tonsillectomy complication than white children.

Tonsillectomy is a relatively safe procedure; however, bleeding is the most common and potentially life-threatening complication (Aljabr et al. 2015). In accordance with other studies (Aljabr et al. 2015; Collison et al.2000), our study also showed there was no significant association between the duration of surgery and posttonsillectomy haemorrhage. The role of various surgical techniques for tonsillectomy has been investigated, as its risk factor. A systematic review by Leinbach et al. (2003) revealed that post-tonsillectomy haemorrhage rates are not significantly different when comparing the cold and hot dissection methods. In our series, there was no statistically significant relationship between the technique of surgery and post-tonsillectomy haemorrhage. A similar finding was noted in studies by Leinbach et al. (2003) and Negm et al. (2017).

This study showed a significant association between smoking and post-tonsillectomy haemorrhage. The similar association was found in the study by Demars et al. (2008) which concluded that smokers have a higher incidence of post-tonsillectomy haemorrhage if they undergo tonsillectomy along with uvulopalatopharyngoplasty but not when tonsillectomy was performed alone. This could be explained by the detrimental effect of smoking on healing which includes microvascular injury, reduced oxygenation, alteration in the oropharyngeal microflora and colonization of potential pathogens (Demars et al. 2008).

There is controversy regarding the steroid administration and post-tonsillectomy haemorrhage. Our research showed a significant association between the use of steroids and post-tonsillectomy haemorrhage. Patients who were given steroids $(25 \%)$ have a higher chance to develop post-tonsillectomy haemorrhage than 
those who were not given steroids $(9.3 \%)$. This result is in agreement with a study conducted by Suzuki et al. (2014) where they concluded that intravenous administration of steroids in children on the day of post-tonsillectomy was an independent risk factor for severe bleeding. Various studies demonstrated the promising effect of steroid in reducing nausea and vomiting post-tonsillectomy (Miyamoto et al. 2018). Windfuhr et al. (2005) in their study indicated that dexamethasone does not have any effect on nausea or vomiting or bleeding following tonsillectomy. Systematic review and meta-analysis by Plante et al. (2012) demonstrated that use of systemic steroids is associated with increased incidence of operative interventions for bleeding episodes. Systematic review and meta-analysis by Bellis et al. (2014) did not demonstrate a statistically significant increase in the risk of post-tonsillectomy haemorrhage with dexamethasone with/without NSAID use in children.

Dhiwakar et al. (2012) in Cochrane review found that antibiotics were not associated with a reduction in significant secondary haemorrhage rates. This is in agreement with our study results. Tonsillectomy has been performed increasingly as an outpatient procedure due to various new techniques, reducing the operating time and peri-operative blood loss (Myssiorek et al. 1996). Due to this shorter hospital stay, most of the patients will approach the general practitioner during the postoperative period. The common presentations are fever, pain, reduced oral intake, halitosis and bleeding. Various literature reviews have shown that post-tonsillectomy bleeding is the most common presentation at the general practitioner and emergency department (Curtis et al. 2015; Kuo et al. 1995; Lee et al. 1996). Generally, most of the bleeding episodes are self-limiting and only a few require conservative or surgical management. However, in rare cases, the bleeding can be massive and can lead on to airway obstruction and hypovolaemic shock. Patients need to be counselled to present to the emergency department if bleeding occurs (Cooper et al. 2016). Sarny et al. (2001) in his study looked at the patients who required hospital admission and intervention. At the time of admission, examination of the oropharynx is important. Patients with normal oropharyngeal examination (no active bleeding or clot in the tonsillar fossa with usual tonsillar slough only) need to be counselled regarding the further bleeding before discharge (Cooper et al. 2016). If there is bleeding, management includes readmission, observation, conservative and surgical intervention (Wetmore et al. 2017). Admission to the hospital for observation is suggested and evaluation in the operative room may be warranted when patients present more than once for evaluation of post-tonsillectomy haemorrhage. In our study, patients with minimal blood clots in the tonsillar fossa were given hydrogen peroxide and ice water gargles initially and observed closely for further bleeding. In cases of active bleeding, the patient will be returned to the operative room for haemostasis under general anaesthesia. The management of post-tonsillectomy haemorrhage in our institution was mostly (54.5\%) by surgical intervention. Various limitations of our study should be considered. First of all, this study was based on retrospective data and the patient selection was not random. This selection biases would underestimate the real problem. There is a possibility that few of our patients with PTH presented to different institutions for management and therefore missed in our study. The rates of PTH recorded in the database may be less accurate compared to those recorded in the prospective study. Regarding the technique of tonsillectomy, only very few of our patients underwent hot dissection method. Our research findings might be susceptible to statistical bias due to the limitation of the availability of pertinent data.

\section{CONCLUSION}

In our study, post-tonsillectomy haemorrhage has been found to affect $10.5 \%$ of the patients. Gender, indication, technique and duration of tonsillectomy, post-operative usage of antibiotics and NSAIDs were not significantly associated with post-tonsillectomy haemorrhage. Older patients, smokers and use of steroids were significantly associated with increased risk of post-tonsillectomy haemorrhage. Recognition of these risk factors should help to identify the patients at risk of post-tonsillectomy haemorrhage. Therefore, the morbidity and mortality due to post-tonsillectomy haemorrhage can be substantially reduced.

\section{ACKNOWLEDGEMENTS}

We would like extend our gratitude to the staffs of the Otorhinolaryngology Department, Hospital Serdang, Malaysia. We are grateful to the Director General of Health for approval of this study and report.

\section{REFERENCES}

Al-Ani, R.M. 2012. Post-tonsillectomy bleeding: Incidence and risk factors running title: PTB: Incidence and risk factors. Iraqi J. Comm. Med. 3: 261-264.

Al-Shehri, A.M.S. 2014. Incidence and potential risk factors of post-tonsillectomy hemorrhage. Bahrain Medical Bulletin 36: 3 .

Alexander, R.J., Kukreja, R. \& Ford, G.R. 2004. Secondary posttonsillectomy haemorrhage and informed consent. Laryngol. Otol. 118(12): 937-940.

Aljabr, I.K., Hassan, F.M. \& Alyahya, K.A. 2016. Posttonsillectomy hemorrhage after bipolar diathermy vs. cold dissection surgical techniques in Alahsa region, Saudi Arabia. Alexandria Journal of Medicine 52(2): 169-172.

Arora, R., Saraiya, S., Niu, X., Thomas, R. \& Kannikeswaran, N. 2015. Post-tonsillectomy haemorrhage: Who needs intervention? Int. J. Pediatr. Otorhinolaryngol. 79(2): 165169.

Bellis, J.R., Pirmohamed, M., Nunn, A.J., Loke, Y.K., De, S., Golder, S. \& Kirkham, J.J. 2014. Dexamethasone and haemorrhage risk in paediatric tonsillectomy: A systematic review and meta-analysis. Br. J. Anaesth. 113(1): 23-42. 
Bhattacharyya, N. 2001. Evaluation of post-tonsillectomy bleeding in the adult population. Ear Nose Throat J. 80(8): 544-549.

Bhattacharyya, N. \& Shapiro, N.L. 2014. Associations between socioeconomic status and race with complications after tonsillectomy in children. Otolaryngol. Head Neck Surg. 151(6): 1055-1160.

Blakley, B.W. 2009. Post-tonsillectomy bleeding: How much is too much? Otolaryngol. Head Neck Surg. 140(3): 288-290.

Cohen, D. \& Dor, M. 2008. Morbidity and mortality of posttonsillectomy bleeding: Analysis of cases. J. Laryngol. Otol. 122(1): 88-92.

Collison, P.J. \& Mettler, B. 2000. Factors associated with post-tonsillectomy hemorrhage. Ear Nose Throat J. 79(8): 640-648

Cooper, L. 2016. Post-tonsillectomy management: A framework. Australian Family Physician 45(5): 289-291.

Coordes, A., Soudry, J., Hofmann, V.M. \& Lenarz, M. 2016. Gender-specific risk factors in post-tonsillectomy hemorrhage. Eur. Arch. Otorhinolaryngol. 273: 4535-4541.

Curtis, J.L., Harvey, B., Willie, S., Narasimhan, E., Andrews, S., Henrichsen, J., Van Buren, N.C., Srivastava, R. \& Meier, J.D. 2015. Causes as costs of ED visits after pediatric adenotonsillectomy. Otolaryngol. Head Neck Surg. 152(4): 691-696.

Demars, S.M., Harsha, W.J. \& Crawford, J.V.M. 2008. The effects of smoking on the rate of postoperative hemorrhage after tonsillectomy and uvulopalatopharyngoplasty. Arch. Otolaryngol. Head Neck Surg. 134(8): 811-814.

Dhiwakar, M., Clement, W.A., Supriya, M. \& McKerrow, W. 2012. Antibiotics to reduce post-tonsillectomy morbidity. Cochrane Database Syst. Rev. 12: CD005607.

Harju, T. \& Numminen, J. 2017. Risk factors for secondary post-tonsillectomy haemorrhage following tonsillectomy with bipolar scissors: Four-year retrospective cohort study. J. Laryngol. Otol. 131(2): 155-161.

Kuo, M., Hegarty, D., Johnson, A. \& Stevenson, S. 1995. Early post-tonsillectomy morbidity following hospital discharge: Do patients and GPs know what to expect? Health Trends 27(3): 98-100.

Kwok, M.M., Subramaniyan, M., Rimmer, J.J. \& Karahalios, A. 2018. Post-tonsillectomy haemorrhage in Australia-A multivariable analysis of risk factors. Aus. J. Otolaryngol. 1: 2 .

Lee, W.C. \& Sharp, J.F. 1996. Complications of paediatric tonsillectomy post-discharge. J. Laryngol. Otol. 110(2): 136-140.

Leinbach, R.F., Markwell, S.J. \& Colliver, J.A. 2003. Hot versus cold tonsillectomy: A systematic review of the literature. Otolaryngol. Head Neck Surg. 129: 360-364.

Liu, J.H., Anderson, K.E., Willging, J.P., Myer, C.M., Shott, S.R., Bratcher, G.O. \& Cooton, R.T. 2001. Post tonsillectomy hemorrhage. What is it and what should be recorded? Arch. Otolaryngol. Head Neck Surg. 127(10): 1271-1275.

Maksimovic, Z., Vranjes, Z., Zubcic, Z. \& Birtic, D. 2007. Incidence of post-tonsillectomy and post-tonsillectomy haemorrhage in 5125 patients operated during the 1994-2005 period at Department of ENT Head and Neck Surgery, Osijek University Hospital in Osijek Croatia. Act Clin. Croat. 46: 247-250.
Miyamoto, Y., Shinzawa, M., Tanaka, S., Tanaka-Mizuno, S. \& Kawakami, K. 2018. Perioperative steroid use for tonsillectomy and its association with reoperation for post tonsillectomy hemorrhage: A retrospective cohort study. Anesthetic Clinical Pharmacology 126(3): 806-814.

Myssiorek, D. \& Alvi, A. 1996. Post-tonsillectomy hemorrhage: An assessment of risk factors. Int. J. Pediatr. Otorhinolaryngol. 37(1): 35-43.

Negm, H., Atef, A., Lasheen, H., Kamel, A.A., Azooz, K. \& Elhoussainy, O. 2017. Factors affecting secondary posttonsillectomy hemorrhage: A case study. The Egyptian Journal of Otolaryngology 33: 50-55.

Perkins, J.N., Liang, C., Gao, D., Shultz, L. \& Friedman, N.R. 2012. Risk of post-tonsillectomy hemorrhage by clinical diagnosis. Laryngoscope 122(10): 2311-2315.

Plante, J.A.F., Zarychanski, R., Lauzier, F., Vigneault, L., Moore, L., Boutin, A. \& Fergusson, D.A. 2012. Effect of systemic steroids on post-tonsillectomy bleeding and reinterventions: Systematic review and meta-analysis of randomized controlled trials. $B M J 345$ : e5389.

Sarny, S., Ossimitz, G., Habermann, W. \& Stammberger, H. 2011. Hemorrhage following tonsil surgery: A multicenter prospective study. Laryngoscope 121(12): 2553-2560.

Spektor, Z., Saint-Victor, S., Kay, D.J. \& Mandell, D.L. 2016. Risk factors for pediatric post-tonsillectomy hemorrhage. Int. J. Pediatr. Otorhinolaryngol. 84: 151-155.

Suzuki, S., Yasunaga, H., Matsui, H., Horiguchi, H., Fushimi, K. \& Yamasoba, T. 2014. Impact of systemic steroids on post tonsillectomy bleeding analysis of 61430 patients using a national inpatient database in Japan. JAMA Otolaryngol. Head Neck Surg. 140(10): 906-910.

Szeremeta, W., Novelly, N.J. \& Benninger, M. 1996. Postoperative bleeding in tonsillectomy patients. Ear Nose Throat J. 75: 373-376.

Tami, T.A., Parker, G.S. \& Taylor, R.E. 1987. Post-tonsillectomy bleeding: An evaluation of risk factors. Laryngoscope 97(11): 1307-1311.

Tomkinson, A., Harrison, W., Owens, D., Fishpool, S. \& Temple, M. 2012. Postoperative hemorrhage following adenoidectomy. Laryngoscope 122(6): 1246-1253.

Wetmore, R.F. 2017. Surgical management of the tonsillectomy and adenoidectomy patient. World Journal of Otorhinolaryngology-Head and Neck Surgery 3: 176e182.

Windfuhr, J.P., Chen, Y.S. \& Remmert, S. 2005. Hemorrhage following tonsillectomy and adenoidectomy in 15,218 patients. Otolaryngol. Head Neck Surg. 132(2): 281-286.

Faculty of Medicine and Health Sciences

Universiti Putra Malaysia

43400 UPM Serdang, Selangor Darul Ehsan

Malaysia

*Corresponding author; email: subhast2@yahoo.com

Received: 5 October 2018

Accepted: 11 January 2019 